\title{
About This Atlas
}

$\mathrm{T}$ he maps in the Atlas of the Transatlantic Slave Trade are grouped in seven parts. The introduction contains maps that provide a broad context for the slave trade, as well as an interpretation and an overview. The maps in part I track the participation of the nations of Europe and the Americas in obtaining, carrying off, and distributing African slaves around the Atlantic world. The maps in the following parts are based on the geography of a voyage. Those in parts II and III identify where slave voyages were organized and where the slave ships obtained captives in Africa. Next came the Middle Passage, the voyage itself, portrayed in part IV as far as maps allow us to portray that experience. The maps in part $\mathrm{V}$ show where the ships took the slaves in the Americas. Finally, the maps in part VI show the geographic dimension of the suppression of the transatlantic slave trade. None of the maps offers information on the movement of captives before they embarked on their voyage from Africa or on their movements after disembarkation in the Americas, although the captions often include comments on this subject.

Although parts II, III, and V focus, respectively, on the outfitting of slave voyages, places of trade in Africa, and places of sale at the end of the Middle Passage, most of the maps also present a larger picture. In part II, the outfitting ports, labeled in red, are the subjects of the maps, but the slave-trading voyages themselves are at the heart of the maps, linking outfitting ports with places of trade in Africa and the Americas. In part III, the focus switches to Africa. Each major port of embarkation, again labeled in red, has its own map. Many of the maps contain bar graphs that present information about the ports where the slave vessels were outfitted. Part V looks at the slaves that survived the Middle Passage: their African coastal origins and their points of disembarkation. Their ports of arrival in the Americas are shown in red. The bar graph on a map again shows the outfitting ports of the vessels carrying captives, this time for vessels arriving in the Americas rather than for those departing from Africa.

Throughout the Atlas, the paths of the slave trade, shown with arrows, connect points of departure and points of arrival, but they are not intended to portray the actual routes of the slave vessels. The width of the paths varies according to the number of slaves that we estimate to have left from a particular region or to have arrived in a particular region. The scale used to draw the paths does 
not remain constant through the Atlas. If a path in one map is wider than a path in another, the wider path does not necessarily represent a greater number of captives. As the legends for the maps make clear, such comparisons are valid only within a given map. To underline this point we have added to many of the paths our estimate of the actual number of slaves carried from one point to another. If the number is located on a path near Africa, it designates departures from the African region or port. If it is located on a path near a region or port in the Americas, it designates arrivals. Because of deaths on the voyages, the sum of departures from all African regions is typically greater than the sum of all arrivals in the Americas.

In one part, however, part IV, the data on the paths reflect not the number of captives but their age and sex ratios, the length of the voyages on which they traveled, and onboard mortality. Again, if a number on a path is located near Africa, it refers to voyages leaving a particular African coastal region. If it is located close to the Americas, it refers to voyages arriving in a particular American region.

Most maps contain tables with summaries of the statistics that label the paths. The table with each map gives some indication of the reliability of the map by showing what share of the data is based on documented information about voyages and what share is based on our estimates. The sum of row 1 in each table (documented statistics) and row 2 (estimated statistics) will correspond to the sum of the statistics shown on the paths (allowing for rounding and the exclusion from the map of some places that only small numbers of slaves left or reached).

Because the range of years covered by the Atlas is very large, we have set the political boundaries in the maps according to three benchmark years: 1650, 1750, and 1850. The year used for a given map is indicated in its legend. Because the boundaries for countries in Europe and the Americas are generally well known, we have not always added country names. But for Africa we have provided, in part III, maps displaying both political units and ethnolinguistic terms. For the limits of the African coastal regions used throughout the Atlas and their relation to modern nation-states, see map 8 . We have used modern names for embarkation points in Africa where these are available. Variations in the dates in the map titles are often the product of the documents available. Readers should note that the trade in African slaves from Europe to the Americas probably began around 1501, but the trade directly from Africa to the Americas began only in 1525. They should also note that the database may have information on departures for a certain span of years, for example, but information on arrivals for a somewhat different span.

Further aid is supplied in a timeline and a glossary of terms, both at the end of this book.

\section{Methodology}

Ninety percent of the maps in the Atlas are constructed from a set of estimates derived from the Trans-Atlantic Slave Trade Database as it existed in January 2008-almost a year before the launch of the Voyages Web site (www.slavevoyages 
.org), which includes the database, formerly available only on CD-ROM. Because the database is constantly updated and corrected as new information becomes available, readers cannot replicate the statistics in this atlas exactly by using statistics found via the search interfaces on the Voyages Web site. The differences between the statistics on the Web site and those in the Atlas are never likely to be major, however, and we do not anticipate that the maps will need to be redrawn anytime soon.

In January 2008 the database underlying the Atlas contained details of 34,934 documented slave voyages. We think that these voyages constitute just over 80 percent of all the slave ventures that ever set out for Africa to obtain slaves from all locations around the Atlantic. With the exception of some maps in the introduction and all those in parts IV and VI, the maps in the Atlas are based on estimates of the slave trade rather than on the raw data of slave voyages. The procedures by which the estimates were drawn from the raw data are identical to those described at the Web site (see http://www.slavevoyages.org/ downloads/EstimatesMethod.pdf, and http://www.slavevoyages.org/downloads/ Estimates-2010.xlsx, both cowritten by David Eltis and Paul F. Lachance). Essentially, estimates of the total slave trade allow for voyages that occurred without leaving any known trace in the historical record. The voyages that we know about are all identified in the database with a number. For those interested in investigating further, we have included a unique "voyage id" number in citing some tables and logbook entries. This number allows the reader to identify the voyage in the Search the Voyages Database interface on the Web site.

Slave voyages could last for two years or more from the time a vessel left the port in which it was outfitted. Groupings of years in the maps are always based on the year of arrival in the Americas. The statistics supplied in most maps are rounded. For numbers below 10,000, rounding is to the nearest hundred; for numbers above 9,999, rounding is to the nearest thousand. This convention results in apparent discrepancies, particularly in comparisons across maps and tables. For example, in map 100, "Luanda: Destinations of Slaves and Home Ports of Vessels Carrying Them, 1582-1850," the table shows disembarkations of 2,433,000 slaves, but the figures on the arrows on the Americas side of the map total only 2,429,900.

Most of the maps in this atlas show elements of the slave trade at a broad scale in order to illustrate the intercontinental connections between regions of slave embarkation, outfitting ports of slaving ships, and final destinations of captives. Inset maps present detailed information that would otherwise be lost on a map showing the entire Atlantic basin. Most of the maps use the Mollweide projection centered on the Atlantic Ocean. The Mollweide is an equal-area projection, meaning that it represents land masses at their true relative sizes. Many readers may not be familiar with this projection and may consider the shape of some land masses to be somewhat distorted in comparison to their representation on other maps. We chose to use the Mollweide in order to display the size of Africa as accurately as possible in relation to the other continents and in order to highlight the large regions of the slave trade and their connections to traders and slave markets in Europe, North America, and South America. 
The maps displaying the political and the ethnolinguistic terms associated with political boundaries in Africa are identical to those at the Voyages Web site and were developed with the aid of specialists in each region of Africa.

Overall, the Atlas presents a fuller picture of the geography and the underlying patterns of the largest forced oceanic migration of people in history than has been possible to date. But it represents only a portion of the journey that these migrants were forced to undergo. The term Middle Passage describes the middle leg of the typical slave-trading voyage that went from Europe to Africa to the Americas, but it is appropriate in another, broader sense. The ocean voyage was also the middle leg of the journey traveled by the typical slave: from the point of capture to the point of embarkation on the African coast was the first leg, the transatlantic voyage was the second leg, and, if the captive survived the voyage, there was a third leg, from the point of disembarkation to the point of ultimate sale. Perhaps one-fifth of all slaves arriving in the New World faced further arduous travel after their arrival. In all the major Brazilian ports captives could be resold into the goldproducing regions of Minas Gerais and Goías or, later, into coffee estates in the southeast. Slaves taken to the Atlantic ports in the Spanish colonies of the mainland Americas usually ended their odyssey in Peru or the interior of Mexico. Possibly as many as one-third of the slaves taken to the eastern Caribbean were sold on to other markets in the Spanish and British Americas.

\section{Sources}

The basic source upon which the Atlas draws is the database at www.slavevoyages .org, which contains records of nearly 35,000 transatlantic slave voyages. In the tables on the maps in this atlas, the rows marked "Documented" present the results of analyzing the data on the Search the Database page of the Web site. The Understanding the Database page of the Web site (http://www.slavevoyages.org/tast/ database/sources.faces?type $=$ documentary) provides a full list of sources used in assembling the records. In the tables on the maps in this atlas, the rows marked "Estimated" refer to the Estimates page at the same site (http://www.slavevoyages .org/tast/assessment/estimates.faces). The larger tables included with the introductions to parts I-VI of this atlas are also calculated from the Search the Database and Estimates pages of the database.

For the construction of the estimates see the "Estimates spreadsheet" section of the database (http://www.slavevoyages.org/tast/database/download.faces), where the relevant spreadsheets may be downloaded. The spreadsheets should be read in conjunction with both the methodology essay by David Eltis and Paul F. Lachance, "Estimates of the Size and Direction of the Transatlantic Slave Trade" (2009), which may be downloaded from the same page, and the essays in David Eltis and David Richardson, eds., Extending the Frontiers: Essays on the New Transatlantic Slave Trade Database (New Haven: Yale University Press, 2008), especially chapter 1 (pp. 1-6o). 
Atlas of the Transatlantic Slave Trade 
This page intentionally left blank 